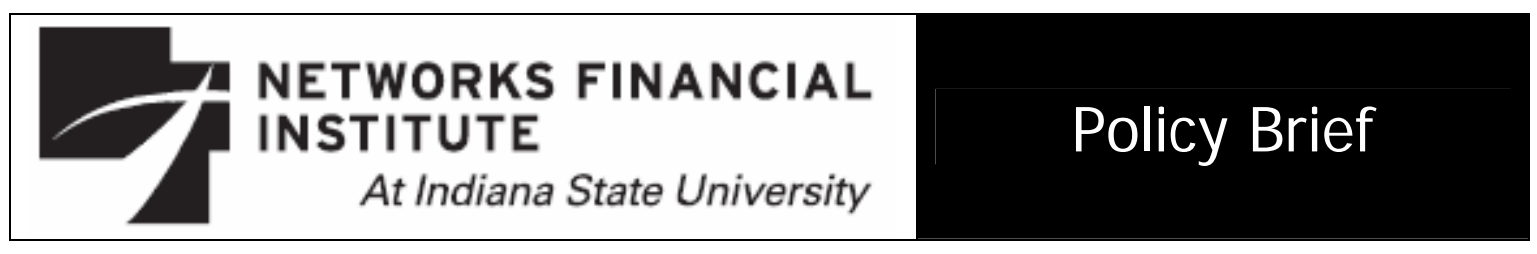

\author{
2005-PB-04 \\ November 2005
}

\title{
Social Security Reform: Can It Secure The Rights To Your Pension Benefits?
}

\section{Thomas R. Saving}

About the Author: Dr. Thomas R. Saving is the Director of the Private Enterprise Research Center at Texas A\&M University. A University Distinguished Professor of Economics at Texas A\&M, he also holds the J eff Montgomery Professorship in Economics. Dr. Saving received his Ph.D. from the University of Chicago and served on the faculty at the University of Washington at Seattle and Michigan State University before moving to Texas A\&M University in 1968. Dr. Saving's research has covered the areas of antitrust economics, monetary economics, and health economics. He has served as a referee or as a member of the editorial board of the major United States economics journals, and he is currently co-editor of Economic Inquiry. His current research emphasis is on the benefit of markets in solving the pressing issues in health care and Social Security. He is the co-editor of Medicare Reform: Issues and Answers, University of Chicago Press, 1999, and the co-author of The Economics of Medicare Reform, W.E. Upjohn Institute, 2000. In addition, he has many articles in professional journals and two influential books on monetary theory. Dr. Saving has been elected to the post of President of the Western Economics Association, the Southern Economics Association and the Association of Private Enterprise Education. In 2000, President Clinton appointed Dr. Saving as a Public Trustee of the Social Security and Medicare Trust Funds. On May 2, 2001, President Bush named Dr. Saving to the bipartisan President's Commission to Strengthen Social Security.

Key words: Social Security, Trust Fund, personal retirement accounts, transition costs

I would like to thank Liqun Liu and Andrew J. Rettenmaier for their helpful discussions.

The views expressed are those of the individual author(s) and do not necessarily reflect official positions of Networks Financial Institute. Please address questions regarding contents to Thomas R. Saving at t-saving@tamu.edu. Any errors or omissions are the responsibility of the author(s).

NFI working papers and other publications are available on NFI's website (www.networksfinancialinstitute.org). Click "Research" and then "Publications." To receive updates about $\mathrm{NFI}$ news, events, and publications, sign up for the NFI e-newsletter at www.networksfinancialinstitute.org 


\section{Social Security Reform: Can It Secure The Rights To Your Pension Benefits?}

\section{Thomas R. Saving}

\section{Introduction}

Social Security has been an extremely popular program over its 70 years of existence. It has provided retirement, life insurance and disability benefits to workers and their families. Through the years, benefits have been expanded and adjusted, new groups of workers have been covered, and taxes have been raised on workers and some retirees to pay for the program's costs. As the program's costs grew, so did its revenue base, as members of the Baby Boom generation matured and reached their peak annual earnings. For the past 20 years, Social Security payroll tax revenues have been in excess of its benefit payments, providing revenues to the Treasury to fund other programs.

The program's surpluses are expected to end in 2017. In all future years, its costs, in the form of benefit payments will exceed its dedicated tax revenues and the gap between cost and revenues is expected to grow each year into the indefinite future. Anyone looking to providing for the continuation of Social Security must deal with this growing funding gap. The projected funding gap is not an illusion made up by those who favor one type of reform over another, but 
a real gap that must and will be dealt with by the present or some future Congress.

The Social Security reform debate is really about how to close this gap essentially how to provide retirement benefits to current retirees as they age and how to provide benefits to new retirees in the very near future. But how future benefits are funded, say through future tax increases or through additional savings today, determines who bears the burden of closing the funding gap and when that burden is borne. Most reformers have as their goal the provision of benefits comparable to the benefits that are currently scheduled. In the present paper I would like to explore how personal retirement accounts provide one avenue to achieving reform.

\section{The Nature of the Problem}

The fundamental problem facing Social Security is summarized in Figure 1, below. Most of those familiar with Social Security know that, beginning in 2017 , its costs, in the form of benefit payments, will exceed its dedicated tax revenues. The gap between costs and revenues grows in every year thereafter. ${ }^{1}$ The present value of the difference between projected costs and revenues over the indefinite horizon is $\$ 12.8$ trillion. Closing this financing gap is the task of all reformers. $^{2}$ 


\section{Figure 1 \\ Projected Social Security Costs and Revenues (OASDI)}

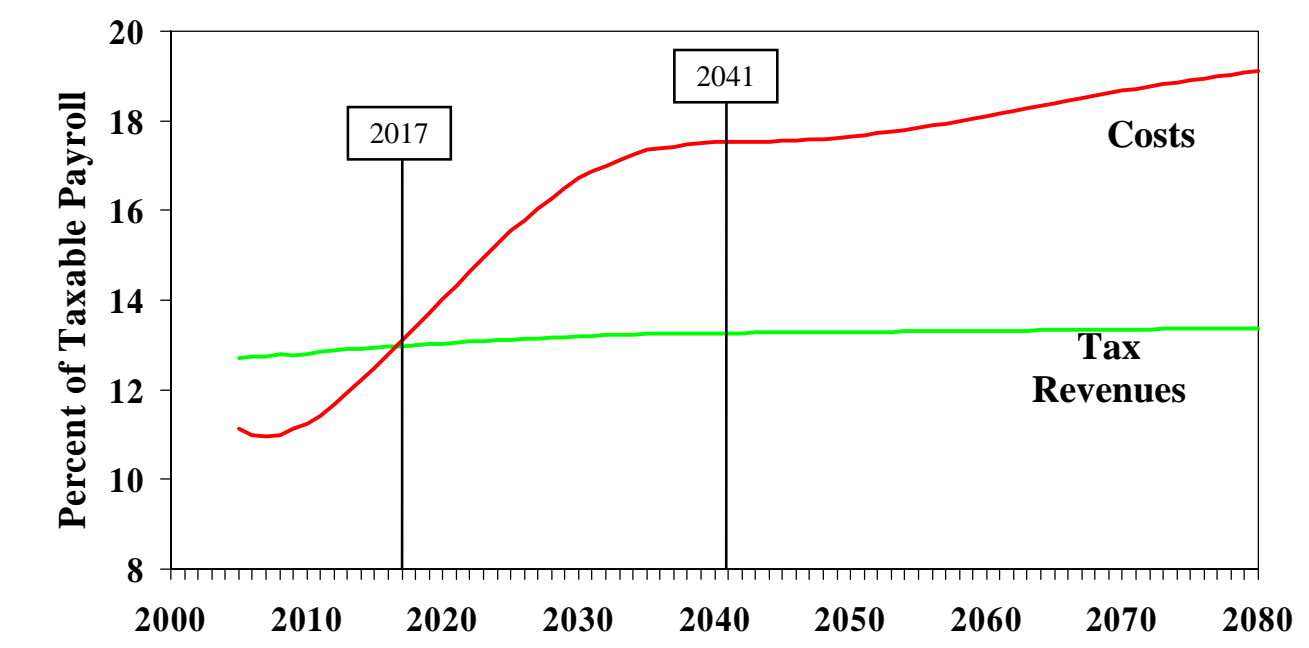

Source: 2005 Trustees Report (OASDI), Table IV. B1.

Before going any further, I must note that some opponents of reform at this time argue that the system is sound until the Trust Fund is exhausted in 2041 and even then, 72 percent of current benefits could still be paid. They are absolutely correct in asserting that the Trust Fund would last until 2041 if currently scheduled benefits are actually paid and only currently scheduled taxes are collected. However, the payment of scheduled benefits requires that a significant share of general revenues be used to pay Social Security benefits rather than finance normal federal government programs. Thus, while the Trust Fund is projected to last until 2041, in a budget context, the Trust Fund provides no revenues to the Treasury, so that its redemption to pay benefits will require belt tightening elsewhere. The actual budget implications of the projected Social 
Security deficits are completely independent of the size of the Trust Fund or even its existence.

Given that there is general agreement that the Social Security system must be fixed, what is the solution? Can't we just stay with the current system? To put this last question into perspective, consider the following. In just 12 years, payroll taxes will fall short of what is needed to continue paying Social Security benefit checks. At that point, the Treasury must begin transferring funds from general revenues to Social Security. The transfers will increase rapidly so that by 2022 , the transfer will reach the equivalent of five percent of total federal income tax revenues, implying that between now and 2022, Congress will lose the equivalent of 12 percent of total federal income tax revenues to Social Security. What, if anything, does this lost revenue portend for Social Security?

Figure 2 shows the past history of Social Security surpluses and deficits as a percentage of federal income tax revenues. In 1978, the payment of Social Security benefits required a general revenue transfer of just over four percent of federal income tax revenues. The response of Congress to this transfer was to change the benefit formula, effectively reducing scheduled benefits for future retirees. The positive effect of this change was short-lived so that by 1983, the system once again required large general revenue transfers to pay benefits. The 1983 general revenue transfer was approximately four and one-half percent of income tax revenues. Once again the response of Congress was to cut benefits, 
by making Social Security benefits subject to income taxation. In 1983, Congress also raised taxes and increased the retirement age. Importantly in 2022 , just five years after Social Security has its first deficit since 1983, the Social Security system will require greater general revenue transfers than Congress has ever allowed before cutting benefits and/or raising. If the past is any indication of the future, we can expect benefits cuts or tax increases no later than 2022, in just 17 years.

\section{Figure 2}

Social Security (OASDI) Surpluses and Deficits as a Percentage of Federal Income Tax Revenues

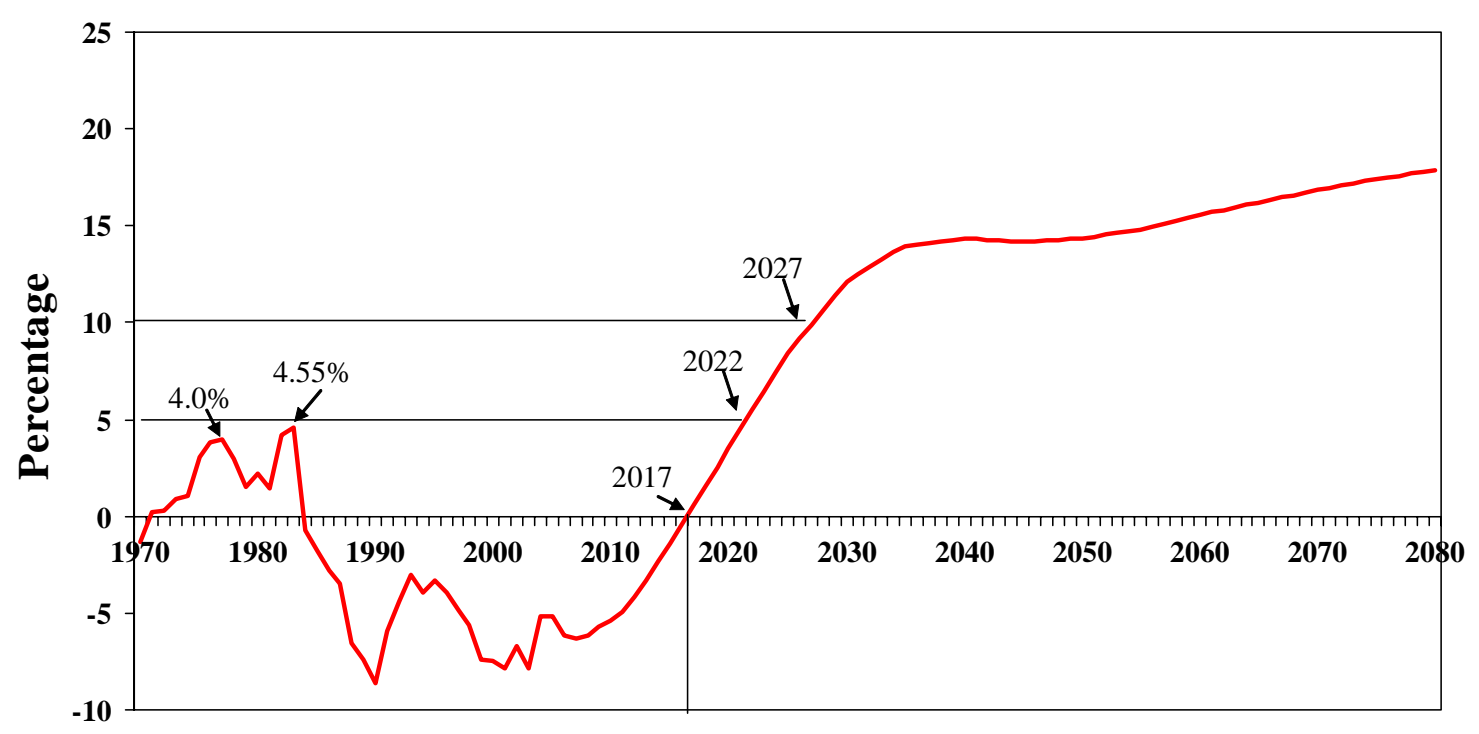

\section{The I mplications of Staying in the Current System}

The long-run forecasted imbalance between payroll tax rates and benefit levels will cost the nation an additional $\$ 12.8$ trillion in today's dollars to keep the 
current benefit structure in place. The unpleasant truth is that if we pay promised benefits and only collect scheduled taxes from the current generation, the next generation will have to come up with $\$ 13.7$ trillion rather than the $\$ 0.8$ trillion they are scheduled to contribute under current law. Thus, the current funding arrangement implies large obligations that the system cannot pay without reform. Thus, the current system has its own very significant "transition costs."

Remaining in the current system entails finding the revenue to pay the scheduled benefits. There are two ways to find the revenue to pay these benefits: (a) allow the payroll tax rate to rise to cover benefits; (b) use general revenues to augment payroll tax receipts. Figure 1 shows the payroll tax rates that would be required to pay the scheduled benefits. Once 2017 is reached, payroll tax rates must rise rapidly from their current level of 12.4 percent to 14 percent in 2020, just three years after the system experiences its first deficit, 15.5 percent just five years later in 2025, and 16.75 percent in another five years, in 2030. These payroll tax rate increases, if implemented, can be expected to have serious effects on labor force participation rates that will require that the revenue estimates in Figure 1, be revised downward.

If general revenues are used to augment payroll tax receipts, then other taxes must rise or federal expenditures must fall. In Figure 3, I show the dollar transfers that must be made from general revenues to pay scheduled benefits. Just ten years after the system experiences its first deficit, $\$ 200$ billion 2005 
dollars must be transferred from general revenues to Social Security if currently scheduled benefits are to continue being paid. Moreover, by the year of forecast Trust Fund exhaustion, 2041, the general revenue transfer will grow to $\$ 355$ billion 2005 dollars. Transfers of this magnitude imply that Congress will be giving up discretion over more than 15 percent of all federal income tax revenues.

\section{Figure 3}

Social Security Surpluses and Deficits 2005\$

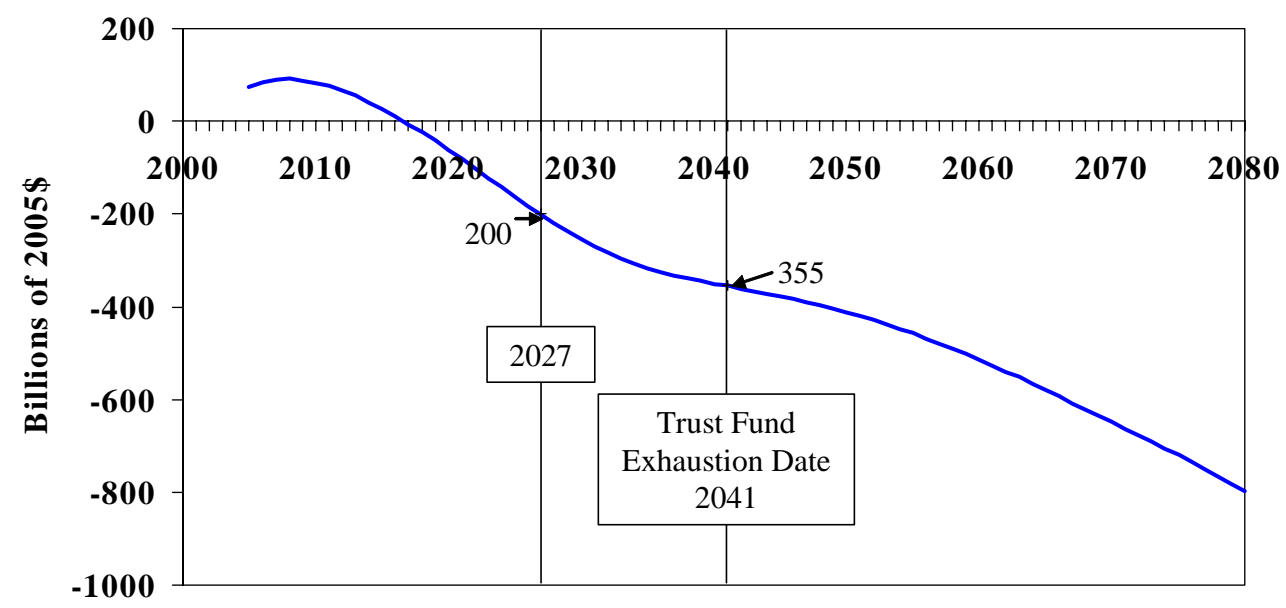

Source: 2005 Trustees Report (OASDI).

\section{Why Not Continue to I nvest the Surpluses in Special I ssue Trust Fund}

\section{Bonds?}

Since the system is required to invest its surpluses in special issue bonds, the trust fund is simply a debt the government owes itself. While from the perspective of the Social Security system, separate from the rest of government, the Trust Fund is an asset, the ultimate redemption of the Trust Fund requires 
that the Treasury provide the funds from government revenues. This relation of the Trust Fund to the overall budget has been well understood as the following statement from the Budget of the United States Government made during President Clinton's administration shows:

"These [Trust Fund] balances are available to finance future benefit payments and other trust fund expenditures-but only in a bookkeeping sense. These funds are not set up to be pension funds, like the funds of private pension plans. They do not consist of real economic assets that can be drawn down in the future to fund benefits. Instead, they are claims on the Treasury that, when redeemed, will have to be financed by raising taxes, borrowing from the public, or reducing benefits or other expenditures. The existence of large trust fund balances, therefore, does not, by itself, have any impact on the Government's ability to pay benefits."

Analytical Perspectives, Budget of the United States Government, Fiscal Year 2000. p. 337.

In effect, the Trust Fund is a bit like the government's left hand writing its right hand a billion dollar bond and then the right hand claiming that its rich. The real danger of Trust Fund accounting is that the public or Congress may be mislead into believing that there is a Trust Fund solution to Social Security's future financial shortfalls. Concentration on the Trust Fund gives credence to a solution that would, for example, increase the interest rate paid on the Trust Fund from its current level of the average rate of interest on government debt of 10 years and under, to six percent real, i.e., inflation adjusted. Indeed, from the perspective of the official definition of solvency, Social Security would be solvent into the indefinite future. But as depicted in Figure 4 below, the general revenue 
transfers necessary to provide currently scheduled benefits would remain unchanged. Thus, while after the increase in interest payments credited to the Social Security Trust Fund it would never be exhausted, from the perspective of the total federal budget, nothing would have changed.

\section{Figure 4}

\section{Social Security Budget Requirements and the Trust Fund} Balance

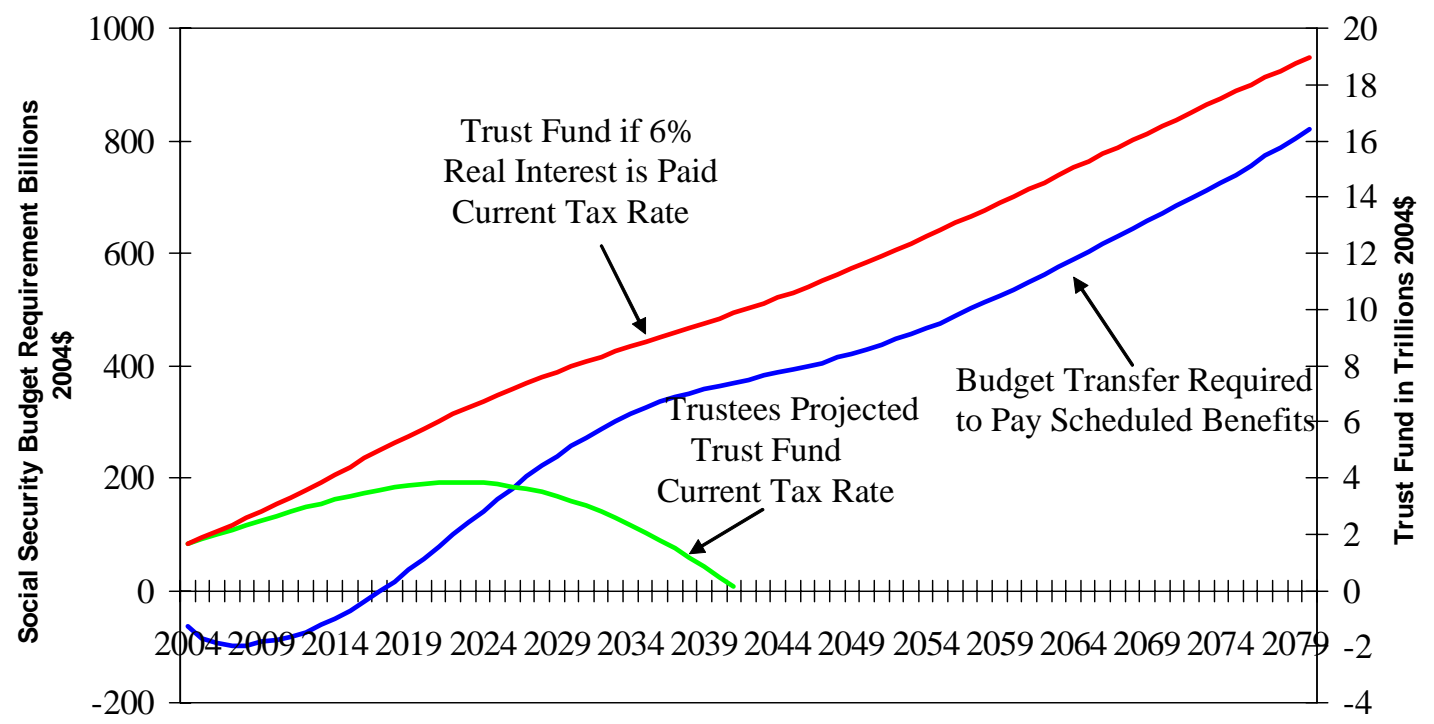

\section{Why Private Accounts?}

To understand the merits of private accounts, we must first understand the level of security provided by the current system. Because of concerns about pension systems in the private sector, in 1975 Congress passed the Employee Retirement Income Security Act (ERISA). This act provided for the oversight of private pension plans and required certain funding and vesting 
provisions. Importantly, Social Security is exempt from ERISA. Or perhaps, it is treated the way many private defined benefit plans are treated. Firms in financial duress are allowed to stop payments into these plans temporarily, resulting in these plans being unfunded or underfunded. Note that any private plan that is based on defined contribution rather than defined benefit does not suffer from this same potential underfunding risk. This distinction is critical when we consider Social Security reform. Defined benefit plans are essentially common property, meaning that all participants own them in common rather than each individual having individual ownership in a specific part of the assets. Defined contribution plans are totally individually owned. Once the funds are in an individual's account, they are untouchable by the firm.

In contrast to private defined contribution plans, Social Security participants have no ownership rights. In effect, as a Social Security participant you have a contract with your Congressman or Congresswoman, the terms of which give them the right to change the contract whenever they like and you have to accept whatever terms they set. Such an agreement would violate both the spirit and literal interpretation of ERISA rules.

The real question is: How can we restructure Social Security so that participants have a real deal where, when the deal is violated, participants have standing in a court of law? An answer, and perhaps the only answer, is personal accounts where each participant has the funds in an account that they fully own. This ownership must not be at the whim of Congress, even though the use of the 
funds before retirement or death may be restricted; once retirement or death occurs, the funds become exactly as any other property.

\section{Comparing Social Security Reforms}

There are a number of reform plans for Social Security and what is needed is a general approach to comparing these plans. Such a comparison must recognize that staying in the current system is not an option, since the current system is unsustainable. There are six questions that the proponents of any reform should answer. First, who participates in the reformed system? Second, is participation voluntary? Third, are participants compensated for accrued benefits? Fourth, how does the reform benefit structure compare to current Social Security's promised benefits, even though these benefits cannot be paid by the current system? Fifth, are there any guarantees, and if so, what do they cost and is the guarantee real? And finally, sixth, how much of the current Social Security debt does the reform pay off?

In light of these six elements and as a frame of reference, let me consider a proposed Social Security reform based in a general way on the parameters suggested by President Bush. The principle elements of this proposed reform answer each of the six questions posed above:

First, all individuals currently 55 years and older must stay in the old system.

Second, participation is voluntary, at any time workers can "opt in" by making a one-time election to enter the new system. Beginning in 2009, 
individual participants under age 59 will be allowed to invest 4 percentage points of their Social Security taxes in private accounts up to $\$ 1,000$ per year. The $\$ 1,000$ cap on contributions will grow $\$ 100$ per year, plus growth in average wages. In return those electing the new system will give up some of their currently scheduled benefits via progressive price indexation where low income benefits will be fully wage indexed while high income benefits will be fully price indexed. ${ }^{3}$

Third, those who stay in the existing system will draw benefits from a reformed and sustainable Social Security system.

Fourth, at retirement, the annuity value of an account that earned the average real rate of return on ten-year government bonds offset the individual's defined benefit payments unless the private account did not achieve the offset rate of return. In that case, the personal account is turned over to Social Security and no defined benefit offset occurs.

Fifth, the total retirement benefit is not guaranteed, but the combination of the private account and the new defined benefit can be expected to equal or exceed currently scheduled benefits for all income classes.

Sixth, a reform based on the President's outline will result in a Social Security system that is sustainable, in fact, with this reform the system goes into surplus in 2055 and the surplus rises each year thereafter. The President's reform pays off $\$ 3$ trillion of the $\$ 13$ trillion current Social Security debt.

This augmented President's plan results in a dual system, part of which is a personal account and the remainder is a defined benefit just as current Social Security. One of the goals of the President was to maintain the same benefit structure as current Social Security. As shown in Figure 5, which shows the composition of benefits for four income groups and birth years 1980 and 2000, the reformed system matures it achieves exactly that, at least in an expected value sense. Once the system reaches the point where all participate, those born in 2000 and after, the President's plan returns full scheduled benefits for all, and even more for low income participants, with one caveat that will be discussed 
more fully below. Figure 5 also shows that as the system matures a greater and greater proportion of total benefits are paid from personal accounts. The percentages reported in the Figure are based on expected values. As a result, because the very low lifetime earnings participants are fully wage indexed, the actual defined benefit for this group would remain at $100 \%$ of currently scheduled benefits even if their private account earned nothing. ${ }^{4}$ 
Another point to bear in mind is that the combination of the four percent accounts proposed by the President and complete price indexation of benefits for higher income participants will in the long run produce benefits for the highest income group that will fall below currently scheduled benefits. ${ }^{\vee}$ Actually, under the rate of return assumptions used here, the private account contribution would have to be 5.4 percent of payroll to maintain expected benefits equal to the benefits currently scheduled for the long-run. However, as I show below, the system here goes into surplus in 2055, and the surplus could be used to increase the contribution rate until the 5.4 percent level is reached.

\section{Figure 5}

Composition of Reformed Benefits for Workers born in 1980 and 2000 by Lifetime Earnings Group

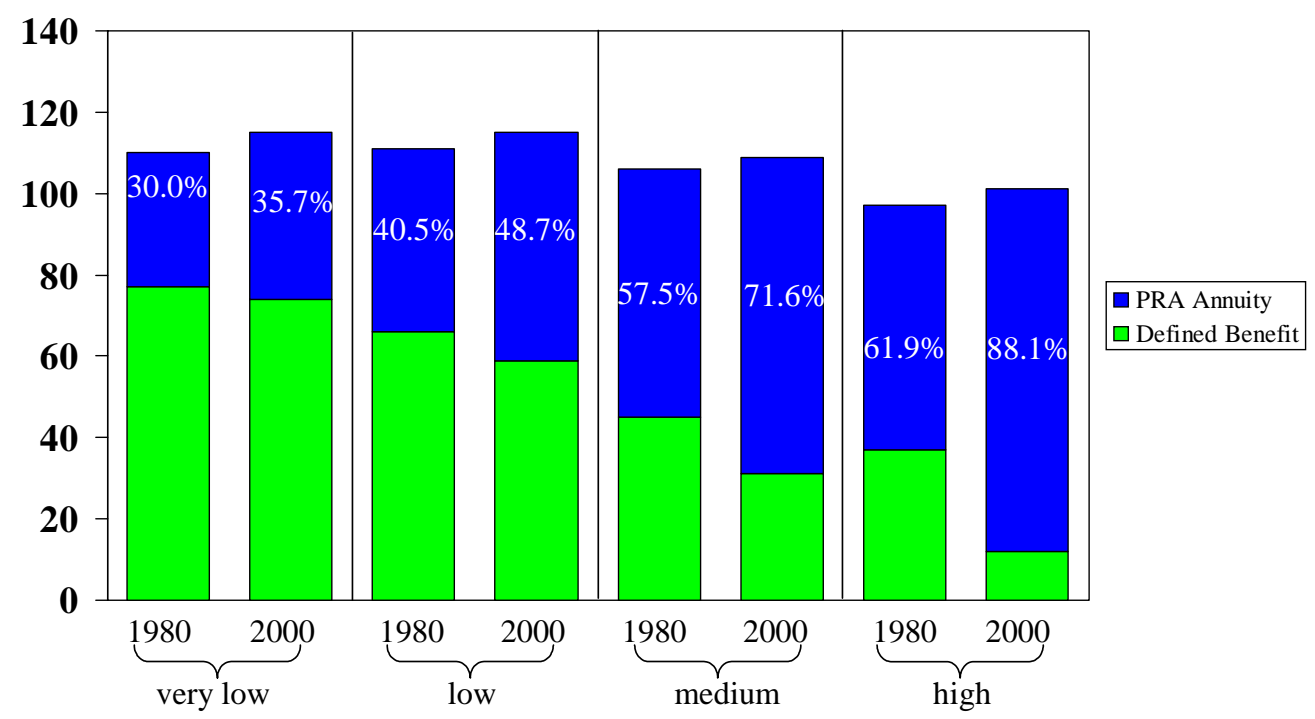

If a reform is to address the solvency problem for the long run, it must be the case that the system revenues under the reform eventually become equal to or greater than the cost of any scheduled benefits. Figure 6 shows the forecast 
revenue and cost of benefits for the reform based on President Bush's proposals.

The lower red cost line is constructed assuming that private accounts achieve the expected return for a $60 \%$ equity $-40 \%$ bond portfolio. ${ }^{\text {vi }}$ Based on this rate of return, the individual accounts offset scheduled benefits so that the system has a positive cash flow beginning in 2055 with the surplus growing each year thereafter.

The design of the Social Security system was to give participants a legal right to their benefits. Unfortunately, a system with Congress as one party to the contract cannot be legally secure. What reform can change the nature of this contract? Only personal accounts can give participants a legal right to their pension benefits. With personal accounts, participants would have standing in a court of law should Congress attempt to change the terms of the Social Security system.

\section{Figure 6}

\section{Annual Revenues and Costs of OASI with and without Reform}

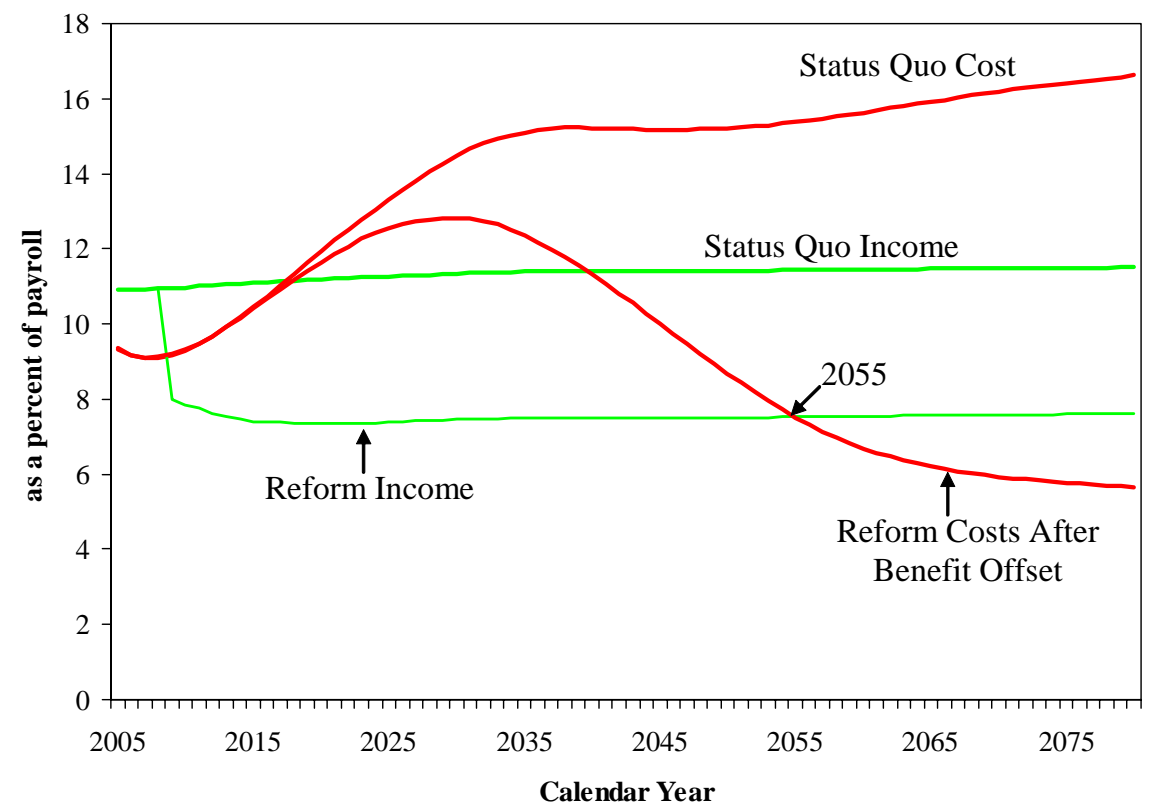




\section{Transition Costs}

The previous discussion provides the backdrop for understanding transition costs. Recent media reports have stated that the transition costs of the personal retirement accounts reform, favored by the president, amount to between $\$ 1$ and $\$ 2$ trillion. What exactly do these estimates quantify? Do transition costs quantify the costs of shifting from the current financing arrangement to a partially prepaid system?

Prepaying Social Security partially or totally simply changes the timing of the financial burden and thus changes the generational burden of the program. However, if the goal of the reform is to pay scheduled benefits as depicted in the graphs, then the present value of those scheduled benefits are the basic costs of the program. Since the current financing arrangement cannot pay these costs, the system must be reformed, but the costs are the same for all reforms. As pointed out above, an important distinguishing characteristic of reforms is in the way they distribute the burden of the program across generations.

With a personal retirement account reform, workers save more and accumulate a fund from which they will purchase an annuity. The goal of most reforms is for the sum of the annuity and the reformed defined benefits to equal the benefits that are currently scheduled. Thus, the reforms do not reduce the 
total combined benefits retirees will receive. However, the reforms do reduce the share of total benefits that will be paid by future taxpayers, and as a result, future taxpayers have a lower burden than they would if all benefits had to be paid for through contemporaneous tax payments.

How the personal accounts are funded determines the ultimate generational burden of the reform. Specifically, if individual contributions are required or additional tax revenues are raised to fund the accounts then the current generation of workers will carry some of the load. If the accounts are fully funded using borrowing, most of the burden will be borne by future workers. Importantly, in either case the reform will solve Social Security's the long-run solvency problems.

\section{Some Concluding Remarks}

All Social Security reforms must deal with the fact that benefits, as currently scheduled, cannot be paid with the current tax rate. Comparing reforms essentially boils down to identifying how different generations will be affected. In addition to reducing the burden on future generations, prepayment with personal retirement accounts has two other collateral benefits. Workers become the owners of their retirement accounts, and increased savings will increase the nation's income relative to the current financing arrangement. For these reasons, such reforms offer a promising alternative in the current policy discussion. 
Finally, when coupled with the pending Medicare shortfalls, we must find a way for the working generation to pay for some of their retirement consumption while they are working. If we pay current law benefits for Social Security and Medicare and only collect current law taxes and premiums, the shortfalls will use up large parts of future federal income tax revenues. Within just fifteen years, in 2020, we will have to transfer more than $29 \%$ of federal income tax revenues to the combination of Social Security and Medicare. The problem worsens rapidly so that just ten years later, more than one-half of all federal income tax revenues will be consumed by Social Security and Medicare. Clearly, these transfers cannot and will not happen. The real issue is how will these programs be changed? The establishment of personal accounts as part of the reform of Social Security can form the basis for beginning the prepayment of all retirement benefits. 


\section{References}

Board of Trustees of the Federal Old-Age and Survivors Insurance and Disability Insurance Trust Funds (2005), Annual Report of the Board of Trustees of the Federal Old-Age and Survivors Insurance and Disability Insurance Trust Funds, April 5, 2005, Washington, D.C..

Garrett, Daniel M. (J uly 1995), "The Effects of Differential Mortality Rates on the Progressivity of Social Security," Economic Inquiry, 33, 457-475.

Liu, Liqun and Andrew J. Rettenmaier (2003), "Social Security Outcomes by Racial and

Education Groups," Southern Economic Journal, 69, 842-864.

The President's Commission to Strengthen Social Security (2001), Strengthening Social Security and Creating Personal Wealth for All Americans, December 21, 2001. 


\section{Endnotes}

\footnotetext{
${ }^{1}$ This greater debt is due to a combination of two events that are occurring worldwide: a population bulge known as "baby boomers," and increased longevity. These two events have allowed the taxes required to fund the retirement of past retirees to be woefully inadequate to fund the much larger retirement population soon to be in place. Even though the "baby boomers" will ultimately pass through the system, their passing does not solve the problem as falling fertility and increased longevity are sufficient to insure that workers per retiree will continue to fall.

${ }^{2}$ In this calculation I have not considered the $\$ 1.7$ trillion Trust Fund as an asset. Had I done so, the debt would be $\$ 11.1$ trillion. See "The 2005 Annual Report of the Board of Trustees of the Federal Old-Age and Survivors Insurance and Disability Insurance Trust Funds.”
}

${ }^{3}$ The 2001 President's Commission to Strengthen Social Security suggested that private accounts offset some of the accumulated debt. More importantly, however, the Commission also suggested that rather than replace a constant share of wage indexed earnings, the defined benefit part of Social Security provide a fixed level of purchasing power for all income groups. This change alone reduces the outstanding debt to existing generations and significantly reduces funding requirements for both new and current generations.

${ }^{4}$ The so-called progressive indexation results in some additional redistribution from higher to lower income individuals. However, the current system is less progressive than it might seem from its highly redistributive benefit schedule due to a positive correlation between lifetime income and longevity. According to Garrett (1995), differences in mortality considerably narrow, and in some cases eliminate, the progressive spread in returns across income classes. Liu and Rettenmaier (2003) also reached a similar conclusion by studying both the rate of return and the present value of the Social Security investment for different racial and education groups.

${ }^{v}$ Given positive income growth, fixing the real defined benefit results in the highest income group defined benefit go to zero in the limit as the ratio of prepaid benefit to defined benefit goes to zero.

${ }^{\mathrm{vi}}$ Specifically, the accounts are assumed to be invested in 60 percent stocks, 24 percent corporate bonds and 16 percent government bonds while workers are between 21 and 57 years of age. The assumed real rates of return are 6.5, 3.5, and 3.0 percent, respectively. The share of stocks begins to decline at age 57, reaching 20 percent by age 62 . 